Matthews, R. E. F. (1954). J. gen. Microbiol. 10, 521-532.

\title{
Effects of some Purine analogues on Tobacco Mosaic Virus
}

\author{
BY R. E. F. MATTHEWS \\ Agricultural Research Council,* Plant Virus Research Unit, Molteno Institute, \\ University of Cambridge and Plant Diseases Division, D.S.I.R. Auckland, \\ New Zealand
}

\begin{abstract}
SUMMARY: When sprayed on the leaves of tobacco plants inoculated with tobacco mosaic virus 8-azaguanine caused a delay in the production of virus, and a delay in the development of systemic infection. From alkaline hydrolysates of the nucleic acid prepared from virus isolated from 8-azaguanine-treated plants, a compound was isolated which had the expected properties of 8 -azaguanylic acid. This evidence together with analytical data showed that in tobacco mosaic virus from 14-day-old infections in 8-azaguanine-treated plants, about $3-4 \%$ of the guanine in the virus nucleic acid was replaced by 8-azaguanine. This incorporation of 8-azaguanine appeared to reduce the infectivity of the virus. Several other purine analogues were ineffective against tobacco mosaic virus. A serological-chromatographic method is described for the estimation of small amounts of tobacco mosaic virus in crude plant extracts.
\end{abstract}

The guanine analogue, 8-azaguanine, has a marked inhibitory effect on lucerne mosaic and cucumber mosaic viruses (Matthews, 1953a). The compound has much less effect on disease development with tobacco mosaic virus (TMV). However it is possible with this virus to make a more detailed investigation of the inhibition. The work described here shows that 8 -azaguanine is incorporated into TMV nucleic acid, and suggests that the compound acts as an inhibitor because virus particles containing it are incapable of further multiplication. A number of compounds related to 8-azaguanine were ineffective. A preliminary report of some of these results has already appeared (Matthews, 1953b).

\section{MATERIALS AND METHODS}

Methods of growing plants, carrying out virus inoculations and treatments with compounds, and testing compounds for effects on disease development were as described by Matthews (1953a). The virus strains used were: the 'Type', 'Astoria', 'Yellow' and 'Tobacco Leaf Curl' cultures maintained at the A.R.C. Plant Virus Research Unit, and a New Zealand 'type' culture which produced similar symptoms to the Cambridge type strain but was not necessarily identical with it.

Isolation of virus. Harvested leaves were frozen, minced, and allowed to thaw slowly at room temperature, and the sap was expressed through muslin. The sap was clarified by heating to $55^{\circ}$ for $3-5$ min. followed by centrifugation at 2200 r.p.m. for $10 \mathrm{~min}$. Virus was precipitated from the supernatant fluid by addition of one-half volume of saturated ammonium sulphate. After centrifu- 
gation, the virus-containing pellet was taken up in water, dialysed, centrifuged to remove insoluble impurities and precipitated a second time with ammonium sulphate followed by dialysis. Yields of virus were estimated by dry weights, by micro-Kjeldahl nitrogen determinations, or by the density of the solutions in ultraviolet light, assuming that $1 \mathrm{mg}$. virus $/ \mathrm{ml}$. gives a density of $3 \cdot 2$ at $260 \mathrm{~m} \mu$. in a $1 \mathrm{~cm}$. cell.

Isolation of nucleic acid. Nucleic acid was isolated from the purified virus preparations by heating to about $95^{\circ}$ (Bawden $\&$ Pirie, 1937) in neutral solution in the presence of small amounts of salt, centrifuging to remove the protein thus coagulated and precipitating the nucleic acid with two volumes of ethanol. The precipitate was then redissolved in slightly alkaline solution, centrifuged at $\mathbf{8 0 0 0}$ r.p.m. to remove further traces of protein, and reprecipitated with ethanol.

Analytical procedures. The chromatographic and electrophoretic procedures used were those described by Markham \& Smith $(1949,1950 a, b, 1952 a)$. Nitrogen was estimated by the micro-Kjeldahl method of Markham (1942) and phosphorus by the method of Allen (1940).

The solvent systems used for paper chromatography were: $i$ sopropanol $+\mathrm{HCl}$ (isopropanol, $170 \mathrm{ml}$; ; conc. $\mathrm{HCl}, 44 \mathrm{ml}$; ; water to $250 \mathrm{ml}$.); isopropanol $+\mathrm{NH}_{3}$ $\left(70 \%\right.$ isopropanol in water $(\mathrm{v} / \mathrm{v})$ with $\mathrm{NH}_{3}$ in the vapour phase); ammonium sulphate + water (sat. $\left(\mathrm{NH}_{4}\right)_{2} \mathrm{SO}_{4}, 80 \mathrm{vol}$.; isopropanol, 2 vol.; $0.5 \mathrm{M}$-sodium acetate, 18 vol.).

Fluorescence printing. The method of printing chromatograms and paper electrophoresis strips by the fluorescence of the spots in ultraviolet light, which was briefly described by Markham \& Smith $(1950 a)$, proved particularly useful. In this method, a thin film of cellulose nitrate ('Celluloid', The Autotype Co. Ltd., Brownlow Road, London, W. 13) which is opaque to ultraviolet light, is placed between the filter-paper and the photographic paper. Cellulose or cellulose acetate film is ineffective, being transparent to ultraviolet light. Thus only fluorescent light from the spots or from the paper will affect the photographic paper. The limitation in the sensitivity of the method is the background fluorescence of the filter-paper. Using the lamp and filter described by Markham \& Smith (1951), cellulose nitrate film 0.08 mm. thick, and Kodak grade 0 or 1 bromide paper, exposures of 10-20 sec. are required for Whatman's no. 1, and 30-50 sec. for Whatman's no. 3 filterpaper. It was found that 8 -azaguanine fluoresces strongly under both acid and alkaline conditions, while guanine compounds fluoresce strongly, if at all, only under acid conditions; for 8-azaguanine the method is about 10 times as sensitive as detecting the spots by absorption. In the absence of relatively large amounts of ultraviolet light absorbing material it is possible to detect about $0.3 \mu \mathrm{g}$. of 8-azaguanine.

Serological-chromatographic method for estimation of virus. The following method which takes advantage of the sensitivity and specificity of both the precipitin reaction and chromatographic procedures was used to estimate TMV in small samples of leaf sap. Frozen leaf samples are ground in a small volume of water, the suspension heated to $55^{\circ}$ for $5 \mathrm{~min}$. and the green 
precipitate removed by centrifugation. The supernatant liquid is mixed with a small excess (previously determined) of an anti-tobacco mosaic virus serum. The mixture is incubated for $1 \mathrm{hr}$. at $50^{\circ}$ and overnight at room temperature. The specific precipitate is centrifuged down, washed once with $0 \cdot 14 \mathrm{M}-\mathrm{NaCl}$ and carefully dried. The precipitate is digested overnight in a known small volume of $2 \mathrm{~N}-\mathrm{KOH}$, and neutralized with the appropriate amount of $\mathrm{HClO}_{4}$. The $\mathrm{KClO}_{4}$ precipitate is centrifuged off. Portions of the supernatant fluid are then subjected to chromatography in the isopropanol + ammonia solvent. The guanylic acid spot and the slightly faster moving spot containing the other three mononucleotides are then eluted in $0.1 \mathrm{~N}-\mathrm{HCl}$ and estimated spectrophotometrically. The method is useful for amounts of virus in the range $0 \cdot 2-10 \cdot 0 \mathrm{mg}$. giving recoveries around $90 \%$.

Compounds. Guanosine (Light and Co.); 8-azaguanine (I), 8-azahypoxanthine (II), 8-azaisoguanine (III), 8-azaxanthine (IV), dimethylamino-8-azaguanine (V) (given by American Cyanamid Co.), 5-amino-7-hydroxy-1, 2, 4, 6-tetraazaindene (VI) (given by Imperial Chemical Industries).<smiles>Nc1nc(O)c2[nH]nnc2n1</smiles><smiles>Oc1ncnc2nn[nH]c12</smiles><smiles>Nc1nc(O)nc2nn[nH]c12</smiles>

III<smiles>Oc1nc(O)c2[nH]nnc2n1</smiles><smiles>CN(C)c1nc(O)c2[nH]nnc2n1</smiles><smiles>Nc1nc(O)c2[nH]ncc2n1</smiles>

\section{RESULTS}

Effect of 8-azaguanine on virus development

When sprayed on the leaves of young tobacco plants at concentrations of c. $0.01 \mathrm{M}$ in solution in sodium bicarbonate, 8-azaguanine caused a delay of several days (usually 3-6) in the appearance of systemic symptoms of TMV 
infection but never prevented eventual systemic development. The compound had this effect on all the strains of the virus that were tested, namely: 'Type' (Cambridge and New Zealand isolates), 'Yellow', 'Tobacco Leaf Curl' and 'Astoria'. Inoculation tests for the presence of virus in uninoculated young leaves showed that this delay in the appearance of symptoms reflected a delay in the movement of virus from inoculated leaves. In inoculated leaves, 8-azaguanine caused a delay in the production of virus measured by infectivity, by yield of virus extractable by the ammonium sulphate procedure, or by particle counts using electron microscopy (Williamson \& Matthews, unpublished). Fig. 1 illustrates this effect when the amount of virus was estimated by infectivity.

\section{Incorporation of 8-azaguanine into the virus nucleic acid}

To prepare virus for analytical work young tobacco plants were inoculated with a type strain in highly infective expressed tobacco sap. The day after inoculation and subsequently every 2 or 3 days 'treatment' plants were sprayed with 0.01 M-8-azaguanine solution. Plants were usually harvested about 14 days after inoculation and the virus was isolated by the ammonium sulphate procedure. The first evidence that incorporation of 8-azaguanine was taking place came from base analyses on the nucleic acid from virus from treated and untreated plants. The nucleic acid samples were hydrolysed for $1 \mathrm{hr}$. at $100^{\circ}$ in $\mathrm{N}-\mathrm{HCl}$ and chromatographed in isopropanol $+\mathrm{HCl}$, a solvent system in which 8 -azaguanine runs with adenine. The results of a number of analyses summarized in Table 1 , indicated a deficiency of about $\mathbf{3 . 5} \%$ in guanine in the nucleic acid from virus from treated plants. This deficiency in guanine was accounted for (within the limits of experimental error) by a corresponding increase in adenine. This result would be expected if 8-azaguanine was replacing some of the guanine in the virus from treated plants. When acid-

Table 1. Molar ratios of bases in nucleic acid of tobacco mosaic virus from control and 8-azaguanine-treated plants

\begin{tabular}{|c|c|c|c|c|}
\hline \multirow[b]{2}{*}{ Base } & \multicolumn{2}{|c|}{$\begin{array}{l}\text { Molar ratios (means of } \\
\text { seven determinations) }\end{array}$} & \multirow{2}{*}{$\begin{array}{c}\text { Difference, } \\
\text { control- } \\
\text { treated }\end{array}$} & \multirow{2}{*}{$\begin{array}{l}\text { Difference } \\
\text { required for } \\
\text { significance } \\
\text { at } 0.01 P\end{array}$} \\
\hline & Control & $\begin{array}{l}\text { 8-Azaguanine } \\
\text { treated }\end{array}$ & & \\
\hline Guanine & $0 \cdot 979$ & 0.943 & -0.036 & 0.024 \\
\hline Adenine & $1 \cdot 103$ & $1 \cdot 134$ & +0.031 & 0.031 \\
\hline Cytosine & 0.817 & 0.815 & -0.002 & 0.021 \\
\hline Uracil & $1 \cdot 101$ & $1 \cdot 110$ & +0.009 & 0.058 \\
\hline
\end{tabular}

hydrolysed nucleic acid from virus from treated plants was run on twodimensional chromatograms (first solvent: isopropanol $+\mathrm{HCl}$; second solvent: isopropanol $+\mathrm{NH}_{3}$ ) a small fluorescent spot was observed behind adenine in the second solvent system, in the position expected for 8-azaguanine. The fluorescent material isolated by this procedure had an electrophoretic mobility on filter-paper in $0.05 \mathrm{M}$-borate buffer at $\mathrm{pH} 9$ corresponding to that of 8-azaguanine. 
However, isolation of a compound as the base is not proof of incorporation into the nucleic acid, and previous claims for incorporation of 8-azaguanine into nucleic acids (Mitchell, Skipper \& Bennett, 1950; Henrich, Dewey, Parks \& Kidder, 1952) are open to this criticism. In alkaline hydrolysates of virus nucleic acid, where all the bases that were in polynucleotides should appear as nucleotides, we have sometimes detected small amounts of free 8 -azaguanine. This material was presumably a contaminant surviving both

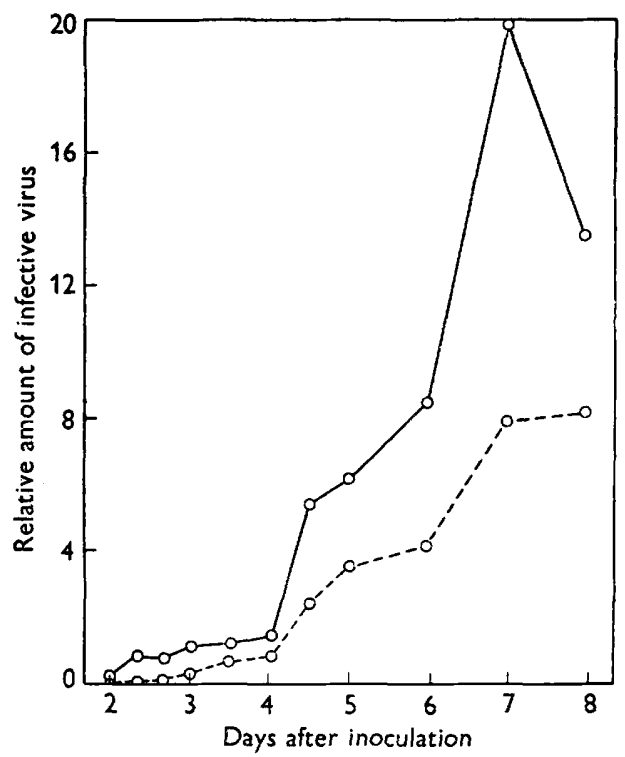

Fig. 1. Effect of 8-azaguanine on tobacco mosaic virus in inoculated tobacco leaves. Solid line: control, untreated plants. Dotted line: 8-azaguanine-treated plants. Test samples were compared with a standard preparation by half leaf comparisons on Nicotiana glutinosa. Relative amount of infective virus is the ratio:

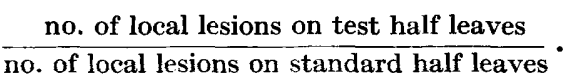

the virus purification and nucleic acid isolation procedures. Therefore to demonstrate incorporation of a compound it would appear necessary to isolate the material as a nucleotide or at least as the nucleoside.

In attempting to isolate 8-azaguanylic from alkaline hydrolysates of nucleic acid advantage was taken of the fact (determined approximately by paper electrophoresis) that the pK's of the hydroxyl and amino groups in the triazolopyrimidines are lower than those for the corresponding purines. In the case of 8-azaguanine the $\mathrm{pK}$ of the hydroxyl group is $\mathbf{2 - 3} \mathbf{p H}$ units lower than that of guanine.

When nucleic acid from virus from 8-azaguanine-treated plants was hydrolysed with N-sodium hydroxide (at room temperature for $\mathbf{2 4} \mathrm{hr}$.) and subjected to electrophoresis on filter-paper in borate buffer at $\mathrm{pH} \mathrm{9,} \mathrm{a} \mathrm{fluorescent}$ band was found, running in a positive direction slightly ahead of uridylic acid, the fastest moving of the naturally occurring mononucleotides at this $\mathrm{pH}$. 
This band, which was absent from control preparations, moved about 1.4 times as fast as 8-azaguanine, and had approximately the mobility to be expected for 8-azaguanylic acid. This procedure was used to isolate the fluorescent material which was further purified by chromatography in isopropanol $+\mathrm{NH}_{3}$. Table 2 gives the approximate $R_{F}$ values of the fluorescent material and other compounds in two solvent systems.

Table 2. Approximate $\boldsymbol{R}_{F}$ values in two solvent systems

\begin{tabular}{|c|c|c|}
\hline & \multicolumn{2}{|c|}{ Solvent systems } \\
\hline & $\begin{array}{c}\text { Isopropanol }+ \\
\text { ammonia } \\
R_{F}\end{array}$ & $\begin{array}{l}\text { Ammonium } \\
\text { sulphate + water } \\
\text { alues }\end{array}$ \\
\hline Guanine & 0.33 & $0 \cdot 16$ \\
\hline Guanylic acid & $0 \cdot 08$ & $\begin{array}{cc}b & 0.33 \\
a & 0.42\end{array}$ \\
\hline 8-Azaguanine & $0 \cdot 27$ & $0 \cdot 17$ \\
\hline 8-Azaguanylic acid & 0.05 & $\begin{array}{ll}b & 0 \cdot 33 \\
a & 0 \cdot 40\end{array}$ \\
\hline
\end{tabular}

In the ammonium sulphate + water solvent, the fluorescent material divided into two spots of roughly equal size running in the expected positions for 8-azaguanylic acids ' $a$ ' and ' $b$ '. This is strong evidence for the production of 8-azaguanylic acid from polynucleotides through the 'cyclic' $\mathbf{2}^{\prime}$ : $\mathbf{3}^{\prime}$ '-monohydrogen phosphates (Markham \& Smith, 1952b) since the ' $a$ ' and ' $b$ ' isomers are stable to alkali.

The ultraviolet absorption spectrum of the fluorescent material isolated from the filter-paper before and after acid hydrolysis is shown in Fig. 2. Guanylic acid has an absorption maximum near $255 \mathrm{~m} \mu$., while with guanine the maximum is near $247 \mathrm{~m} \mu$. The fluorescent material had a maximum at $255 \mathrm{~m} \mu$., which shifted on acid hydrolysis to about $247 \mathrm{~m} \mu$., the position of maximum absorption for 8-azaguanine. After acid hydrolysis the material had the chromatographic and electrophoretic properties of 8 -azaguanine. The material contained phosphorus, and the base : phosphorus ratio from two estimations (made on $0 \cdot 5-1 \cdot 0 \mu \mathrm{g}$. of phosphorus) was $1 \cdot 0: 0 \cdot 83$. From the above facts we conclude that the compound is 8-azaguanylic acid (as a mixture of 8-azaguanosine $2^{\prime}$ and $3^{\prime}$ phosphates) and therefore that 8-azaguanine had been incorporated into the nucleic acid of tobacco mosaic virus.

\section{Effect of 8-azaguanine incorporation on infectivity}

It is possible to compare the infectivity of two virus preparations by estimating the total amounts of virus material present by some physical or chemical means and comparing these estimates with those obtained by infectivity measurements on the same preparations. By such comparisons we attempted to determine whether virus preparations containing 8-azaguanine were less infectious than control preparations. In a number of experiments using material from 14-day-old infections, K. Williamson and the writer estimated 
the amount of virus by infectivity, by extraction of virus and estimation of yield by nitrogen, and by particle counts using electron microscopy. In no case did the infectivity per particle or per weight of virus extracted, in virus from treated plants, differ significantly from control virus preparations. However, material from 3-day infections from treated plants consistently gave a lower ratio of infectivity to total virus than did control preparations, when total virus was measured by the amount of virus isolated by the ammonium

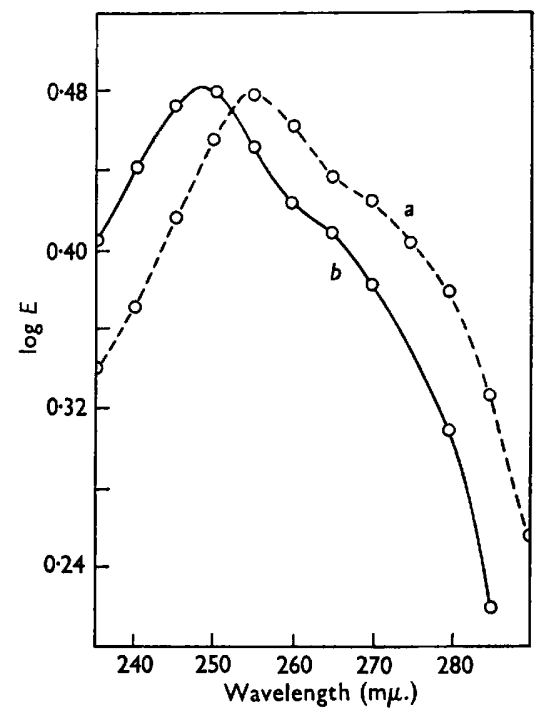

Fig. 2. Ultraviolet absorption spectrum in $\mathrm{N} / 10-\mathrm{HCl}$, of 8 -azaguanylic acid from tobacco mosaic virus nucleic acid: (a) before hydrolysis; (b) after hydrolysis in $\mathrm{N}-\mathrm{HCl}$ for $\mathbf{l ~ h r}$. at $100^{\circ}$.

sulphate precipitation procedure, by precipitin end-point, or by the serological-chromatographic method. In these experiments young tobacco plants were sprayed with $0.01 \mathrm{M}$-8-azaguanine on the 2 days following inoculation, and inoculated leaves were harvested on the third day. Control plants were sprayed once with $0.02 \mathrm{M}-8$-azaguanine about $2 \mathrm{hr}$. before harvesting. The relative infectivities of control and treated expressed sap were determined by inoculation to half leaves of Nicotiana glutinosa. Appropriate dilutions were determined by preliminary tests, and were adjusted to give an average of between 10 and 100 local lesions/half leaf, and approximately to equalize the numbers given by both samples. The data, summarized in Table 3, suggest that roughly half the virus particles in 8 -azaguanine-treated plants were rendered noninfectious.

\section{Distribution of 8-azaguanine among the virus particles}

Using the size and density of the fluorescent spot of 8-azaguanylic acid obtained from a known total density of nucleotides as an approximate estimate of amount, it was found that, in 14-day infections, there was much more 8 -azaguanine in virus from inoculated leaves than in that from systemically 
Table 3. Effect of 8-azaguanine incorporation on the infectivity of tobacco mosaic virus in 3-day-old infections

Ratio of amount of virus in tobacco sap 8-azaguanine-treated/control determined by

(a)

Expt.
no.
1
2
3
4
5
6

Infectivity
$0 \cdot 42$
$0 \cdot 20$
$0 \cdot 29$
$0 \cdot 25$
$0 \cdot 35$
$0 \cdot 40$

(b)

Extraction
of virus
$0 \cdot 93$
$0 \cdot 37$
$0 \cdot 82$
-
-

(c) Serological chromatographic method

-
-
--
$0 \cdot 50$
$0 \cdot 61$
$0 \cdot 65$

(d)

$\begin{array}{cccc}\begin{array}{ccc}\text { Precipitin } \\ \text { end-point }\end{array} & \overbrace{a / b} \text { Ratios } \\ - & 0.45 & - & a / d \\ - & 0.54 & - & - \\ - & 0.35 & - & - \\ 0.50 & - & 0.50 & 0.50 \\ 0.71 & - & 0.57 & 0.49 \\ 0.71 & - & 0.62 & 0.55\end{array}$

infected leaves. This suggests that early-formed virus contains more 8-azaguanine than that formed later, and therefore that in the preparations used for analyses the 8-azaguanine was not randomly distributed among the virus particles.

Attempts to fractionate 8-azaguanine containing virus preparations

By centrifugation. TMV was prepared from 8-azaguanine-treated plants 14 days after inoculation. The method used was that described by Bawden \& Pirie (1945) which minimizes aggregation of the virus rods during extraction. The extracted sap was centrifuged at 16,000 r.p.m. in a Servall S.S. 2 centrifuge for $1 \mathrm{hr}$. Electron microscopic examination showed that the pellet consisted largely of long rods, while in the supernatant liquid short rods predominated. Nucleic acid was prepared from both samples. There appeared to be no difference in the amount of 8-azaguanylic acid as estimated by the size and intensity of the fluorescent spot.

By serological cross-absorptions. It seemed possible that incorporation of 8 -azaguanine into the virus nucleic acid might cause some change in the protein part of the virus which could be detected by serological means. Two antisera were prepared in rabbits against control virus, and 2 against 8-azaguanine containing virus. Cross-absorption tests between antisera against control and 8-azaguanine containing virus failed to reveal any differences.

By milling plant fibre. Bawden \& Pirie (1945) showed that the fibrous leaf residue remaining after the sap had been expressed yielded further virus material when processed in a colloid mill. With 8-azaguanine-treated plants, virus obtained by milling of the fibre contained about the same amount of 8 -azaguanylic acid as that obtained from the sap.

\section{Effect of reversal of 8-azaguanine inhibition by guanosine}

With lucerne mosaic virus the inhibitory activity of 8 -azaguanine is annulled by several normal purines (Matthews, 1953a). To test the effect of a normal purine on 8-azaguanine incorporation, guanosine was used rather than guanine because of its much greater solubility. Four sets of tobacco 
plants were inoculated with type TMV and $2 \mathrm{hr}$. later each set was given one of the treatments listedb elow. Treatments were repeated on the two following days. Plants were harvested on the fifth day and the virus extracted and estimated. Yields (expressed as $\mathrm{mg} . / \mathrm{ml}$. in clarified sap) were:

$\begin{array}{ll}\text { Control, water sprayed } & \mathbf{1 . 7} \\ \text { Sprayed 8-azaguanine } 0.005 \mathrm{M} & \mathbf{0 . 9 6} \\ \text { Sprayed guanosine } 0.01 \mathrm{M} & \mathbf{2 \cdot 1} \\ \text { Sprayed 8-azaguanine } 0.005 \mathrm{M}+\text { guanosine } 0.01 \mathrm{M} & \mathbf{1 . 9}\end{array}$

The size of the 8-azaguanylic acid spot obtained from similar amounts of alkaline-hydrolysed nucleic acid showed that in the virus from plants treated with guanosine plus 8-azaguanine, there was very much less incorporation than in that from plants treated with 8 -azaguanine alone.

\section{Effect of other purine analogues}

8-Azahypoxanthine, 8-azaxanthine, 8-azaisoguanine and dimethylamino8-azaguanine had no effect on disease development or on yield of virus, and no 8-azaguanylic acid could be detected in virus preparations from treated plants. We have so far had insufficient 8-azaadenine for adequate tests. The compound 5-amino-7-hydroxy-1, 2, 4, 6-tetraazaindene had no effect on disease development.

\section{DISCUSSION}

The isolation of a compound with the expected properties of 8-azaguanylic acid, together with the analytical data on the ratios of bases in the nucleic acids, demonstrates that in TMV from 14-day infections in plants sprayed with 8 -azaguanine, about $3 \%$ of the guanine residues are replaced by 8 -azaguanine. The problem of estimating the specific activity of virus preparations is a difficult one, and none of the methods available for estimating TMV is entirely free from criticism. However, all the methods used in this work agree in suggesting that in 3-day infections treated with 8-azaguanine roughly half the virus particles are rendered non-infectious. There are two possible alternative explanations for this result. First, the 8-azaguanine preparations might contain a contaminant not present in the control preparations. Such a contaminant would have to contain nucleic acid and precipitate with tobacco mosaic virus antiserum. It would also need to be stable to slow thawing of the plant extract, heating to $55^{\circ}$ for 3-5 min. and precipitation with one-third saturated ammonium sulphate. As Pirie (1950) points out, such stability is unlikely for a plant nucleoprotein. Secondly, normal immature non-infectious forms of the virus might exist and be present to a greater extent in the 8-azaguanine containing preparations since less multiplication had taken place. There is at present no evidence for the existence of such forms of the virus. To explain the present results, the immature form should have the properties noted above for a contaminant. Bawden \& Pirie (1945) separated tobacco mosaic virus preparations into fractions of different average sizes. Fractions containing a predominance of small particles were less infectious. However, they found no consistent variation in relative amount of the less 
infectious fraction, in preparations harvested during the period of virus increase from 10 days to 4 weeks after inoculation. There was thus no evidence that the less infectious fractions were immature forms. Since there is evidence that the 8-azaguanine is not randomly distributed among the virus particles in a preparation, the early-formed virus containing more than that formed later, we can make no estimate of how many guanine residues must be replaced by 8-azaguanine to make a particle non-infectious. Indeed the effectiveness of the compound may depend on particular positions being occupied rather than on the total number of guanine residues replaced.

Treatment of plants with 8-azaguanine delays the production of virus when amount of virus is measured by infectivity or by other methods. We have calculated from counts made on thin sections of tobacco leaf tissue that not more than about $10 \%$ and more probably about $0.1 \%$ of the cells of a tobacco leaf are infected when inoculated with a highly infective virus preparation. The rate of increase of virus will therefore depend on two effects: rate of multiplication in individual cells and rate of invasion of fresh cells. For this reason alone, little can be inferred from growth curves, for plant viruses at least, regarding the effect of a compound on actual rate of virus multiplication.

The evidence so far obtained suggests that 8 -azaguanine is sufficiently similar to guanine to be incorporated into the virus nucleic acid, but different enough to make the nucleic acid containing it non-functional, thus rendering the virus particle incapable of further multiplication. The compound appears to be most effective at the site of inoculation, where its concentration is highest and the amount of virus multiplying is lowest. Most of the 8-azaguanine absorbed is fairly rapidly inactivated by conversion to 8-azaxanthine (Matthews, 1953 $b$ ).

It seems unlikely that 8-azaguanine itself will be of any practical value in control, at least for the plant viruses we have tested. However, modifications of the compound which resulted in greater incorporation of 8-azaguanine might give greater inhibition. A compound with any of the following properties might be incorporated to a greater extent than 8-azaguanine: $(a)$ less susceptibility to deamination in vivo; (b) greater solubility allowing greater absorption; (c) more directly on the path of incorporation into nucleic acids.

Compounds which may have some of these properties are:

(a) Compounds containing 8-azaguanine: (i) 8-azaguanosine; (ii) 8-azaguanosine diphosphates $\left(2^{\prime}: 5^{\prime}-, 3^{\prime}: 5^{\prime}\right.$-, or $2^{\prime}: 3^{\prime}$ cyclic $5^{\prime}$-); (iii) 8-azaguanylic acids $\left(2^{\prime}-, 3^{\prime}-, 5^{\prime}-\right.$, or $2^{\prime}: 3^{\prime}$ cyclic phosphates); (iv) dinucleotides, etc., containing 8-azaguanine.

(b) Potential precursors of 8-azaguanine: (i) $5^{\prime}$ amino-1 $\mathrm{H}, 1,2,3$, triazole4-carboxyamide and its riboside and ribonucleotides; (ii) 8-azapurine substituted in the $\mathbf{2}^{\prime}$ position.

There is at present no evidence that units larger than mononucleotides can be incorporated into nucleic acids. If, however, it should be found that small polynucleotides can be utilized in nucleic acid synthesis, it would be of interest to determine the relative inhibitory effects of 8 -azaguanine incorporated into small polynucleotides of various types containing the normal bases. It is 
possible that such compounds could control, to some extent, the distribution of the 8-azaguanine residues in the whole nucleic acid. They might also lead to a preferential incorporation into one type of nucleic acid and thus allow the difference in sensitivity to the compound between host tissues and virus to be increased.

In work to be published elsewhere we have confirmed the finding of Commoner \& Mercer (1952) that 2-thiouracil inhibits the development of tobacco mosaic virus. Jeener \& Roseels (1953) using ${ }^{32} \mathrm{~S}$ labelled 2-thiouracil claimed on the basis of radioactivity data that under conditions giving about $50 \%$ virus inhibition thiouracil replaced $20 \%$ of the uracil in TMV nucleic acid. We have so far been unable to confirm this observation using methods that should have been sensitive enough to detect the presence of thiouracil if only $5 \%$ of the uracil in the nucleic acid had been replaced by this compound.

In searching for other purine or pyrimidine-like compounds which could be incorporated into nucleic acids in may be more profitable to examine those with modifications in the purine or pyrimidine ring, rather than in the substituent groups, although the facts are as yet too few to make any firm generalization possible. It may be that for some reason 8-azaguanine is unique in being able to be incorporated into nucleic acids. If, however, other types of analogue can be found which will replace normal bases, we may obtain information about the structure of nucleic acids in relation to their function of a type not possible with either degradative or X-ray studies. For example the data obtained with 8-azaguanine suggest that in tobacco mosaic virus nucleic acid the carbon of position $\mathbf{8}^{\prime}$ in guanine is not essential for guanine incorporation and that a nitrogen in position $8^{\prime}$ can replace carbon during incorporation but is unsuitable in the process of reduplication. The facts that dimethylamino-8-azaguanine had no effect on virus development and could not be shown to be incorporated suggest that the integrity of the amino group is essential for incorporation. The modification of guanine in which the carbon of position 8 and the nitrogen of position 9 are interchanged was ineffective against several plant viruses. This is probably because a nitrogen atom is necessary in position 9 for the formation of a nucleotide of the normal configuration.

I wish to thank Dr R. Markham for much useful discussion; Mr P. R. Fry for a number of virus preparations, and the American Cyanamid Co. and Imperial Chemical Industries for supplies of compounds.

\section{REFERENCES}

Aluen, R. J. L. (1940). The estimation of phosphorus. Biochem. J. 34, 858.

Bawden, F. C. \& Pirie, N. W. (1937). The isolation and some properties of liquid crystalline substances from solanaceous plants infected with three strains of tobacco mosaic virus. Proc. Roy. Soc. B, 123, 274.

Bawden, F. C. \& Pirre, N. W. (1945). The separation and properties of tobacco mosaic virus in different states of aggregation. Brit. J. exp. Path. $26,294$.

Commoner, B. \& Mercer, F. L. (1952). The effect of thiouracil on the rate of tobacco mosaic virus biosynthesis. Arch. Biochem. Biophys. 35, 278. 
Heinrich, M. R., Dewey, V. C., Parks, R. E. Jr. \& Kidder, G. W. (1952). Incorporation of 8-azaguanine into the nucleic acid of Tetrahymena geleii. J. biol. Chem. 197, 199.

Jeener, R. \& Roseels, J. (1953). Incorporation of 2-thiouracil ${ }^{35} \mathrm{~S}$ in the ribonucleic acid of tobacco mosaic virus. Biochim. Biophys. Acta, 11, 438.

MARKhaM, R. (1942). A steam distillation apparatus suitable for micro-Kjeldahl analysis. Biochem. J. 36, 790.

Markham, R. \& Smith, J. D. (1949). Chromatographic studies of nucleic acids. 1. A technique for the identification and estimation of purine and pyrimidine bases, nucleosides, and related substances. Biochem. J. 45, 294.

Markham, R. \& Smith, J. D. (1950a). Chromatographic studies on nucleic acids. 2. The quantitative analysis of ribonucleic acids. Biochem. J. 46, 509.

Markham, R. \& Smith, J. D. (1950b). Chromatographic studies on nucleic acids. 3. The nucleic acids of five strains of tobacco mosaic virus. Biochem. J. 46, 513.

Markham, R. \& Smith, J. D. (1951). Chromatographic studies on nucleic acids. 4. The nucleic acid of turnip yellow mosaic virus, including a note on the nucleic acid of tomato bushy stunt virus. Biochem. J. 49, 401.

Markham, R. \& Smith, J. D. (1952a). The structure of ribonucleic acids. 1. Cyclic nucleotides produced by ribonuclease and by alkaline hydrolysis. Biochem. J. $52,552$.

Markham, R. \& Smith, J. D. (1952b). The structure of ribonucleic acids. 2. The smaller products of ribonuclease digestion. Biochem. $J .52,558$.

Matthews, R. E. F. $(1953 a)$. Chemotherapy and plant viruses. J. gen. Microbiol. 8, 277.

MAtThEws, R. E. F. $(\mathbf{1 9 5 3} b)$. Incorporation of 8-azaguanine into nucleic acid of tobacco mosaic virus. Nature, Lond. 171, 1065.

Mrtcheli, J. H., Skipper, H. E. \& BennetT, L. L. (1950). Investigations of the nucleic acids of viscera and tumour tissue from animals injected with radioactive 8-azaguanine. Cancer Res. 10, 647.

PIRIE, N. W. (1950). The isolation from normal tobacco leaves of nucleoprotein with some similarity to plant viruses. Biochem. J. 614, 47 . 